value, as it causes relaxation of the pylorus in addition to inhibiting the secretion of the gastric juice. As there is certain to be more or less continuous gestric secretion, the stomach should be washed out with an alkaline solution every evening. If the symptoms do not disappear after four weeks, or if they recur in spite of careful dieting, an operation should be advised.

\section{PREVALENT RAIN-BhARING WINDS AND THE MILK SUPPLY OF MANCHESTER DURING THE YEARS 1896-1909.}

By W. GORDON, M.A., M.D.Cantab., F.R.C.P.Lond., PHYSICIAN TO THE ROYAL DEVON AND EXETER HOSPITAC; PHYSICIAN TO THE WEST OF ENGLAND EYE INFIRMARY.

Is the spring of last year Professor Delépine of Manchester read before the Royal Society of Medicine a very valuable and interesting paper dealing chiefly with the distribation of bovine tuberculous mastitis amongst the farms supplying Manchester with milk. 1,524 farms scattered over an area of nearly 5,000 square miles were carefally investigated and mapped, and it was found that remarkable differences in the prevalence of the disease existed between different districts. Professor Delépine endespoured to use these differences in prevalence to demonstratte a relation between local incidence of tuberculous mastitis and local state of cowsheds and herds, a relation which, if possible to prove, is obviously of profound importance.

There can be nothing but admiration, in considering this paper, for the way in which the available facts have been collected and arranged, for the great time, labour and skill expended on them, and, not least, for the frank indication of the unavoidable limitations of the material. But with all these in view, seeing the importance of the subject and the apparent magnitude of the opportunity, one cannot but deplore that the result attained fell so far short of being conclusive. While presenting considerable - evidence of the influence of what may be called "farm -management" in determining a higher or lower degree of prevalence of the disorder, Professor Delépine found himself unable to escape from the embarrassment of some other influence or influences which were unknown to him.

In quoting the following passages from his paper I hope he will not consider I have in any way misrepresented his conclusions. I have lettered the first two paragraphs (A) and (B) respectively for convenience of reference further on. The lettering and figures in the text here and throughout this paper refer to his maps in the Proceedings of the Royal Society of Medicine. ${ }^{1}$

(A) It would appear from this that in every respect the shippons which were found to produce taberculous milk were worse than the others [worse as regards the state of the cowsheds and herds]. But if instesd of comparing the averages only one compares in each group the state of the tuberculousend nontuberculous farms in various latitudinal zones, it becomes evident that the averages do not convey the whole truth, for if the non-tuberculous farms situated south of Manchester (Group A, Division XX to XXXI) are compared with the tuberculous farms also situated south of Manchester, one finds that the 'lous farms also situated south of Manchester, one finds that the really more satisfactory then the non-tuberculous farms in Zone XX to XXXI, and that it is only south of Zone XXII that the tuberculous farms are worse in every respect than the non-tuberculous farms (not including the Manchester farms).

(B) Another unexpected fact is obvious. Of the five divisions of tuberculous farms, the one corresponding to Zones XXIII and XXIV is undoubtedly the worst, while Division III to XIX is distinctly the best; but notwithstanding the considerable differences indicated in the table, the number of cows with tuberculous udders per cent. of the total number of cows is about the rame in all the zones. The same may be said of the cows sugpected of disesse of the adder; there are slight differences, but these do not correspond in the least with the condition of the farms in the respective zones. I do not think that the differences in these percentages should be taken to indicate important differences in the incidence of taberculosis, as they may possibly be affected by the more frequent inspection of the proximal farms, which would almost certainly lead to the discovery of some few cases overlooked in the first visits.

It is, however, clear that the condition of the farm, though important, is not the dominant factor, and this makes it necessary to believe in the existence of some cause crpable of overpowering the most favourable conditions, and practically independent of the most influential predisposing factors, to account for the focal distribution of cases of tuberculous mastitis.
A careful consideration of the statistical facts recorded in this paper and of facts which I have observed in connexion with a number of farms that I have been able to study closely has led me to the conclusion that cows in a state of advanced taberculosis, and emitting discharges loaded with tubercle bacilli, constitute the chief factor determining the distribation of bovine taberculosis.?

Reviewing these statements and the facts recorded in his paper, it is evident that Professor Delépine is correct in thinking that some other influence (or influences) which he had not taken into account had interfered with his result, preventing him from demonstrating the relation, which he has otherwise made so probable, between farm management and the prevalence of bovine taberculous mastitis. His assumption, however, that this influence is that of "cows in a state of advanced tuberculosis, and emitting discharges loaded with tubercle bsoilli," cannot be admitted, so far as the distribution of disesse amongst the whole number of farms (tuberculous and nontuberculous) is concerned.

Such discharges may, it is true, account for the fact that within the different groups of tuberculous farms-that is, amongst farms where advanced cases are generally present (since cows with tuberculous mastitis " are, in the majority of cases, suffering also from more or less advanced taberculosis of other organs ") $)^{8}$-no sanitary measures short of the removal of these cases appeared to make much difference in the percentage of cows suffering from taberculous mastitis; and we may conclude, with Professor Delépine, that this reasonable explanation meets the diffioulty raised in his paragraph which I have lottered (B). But it is impossible so to explain away the difficulties relerred to in paragraph $\mathbf{A}$, or to account for the distribution of tuberculous farms amongst the whole number of farms. Professor Delépine himself tells us" that "although infection from farm to farm is not impossible, it is not of common occurrence." Besides; even if one admitted the assumption to be a possible truth-which cannot be done-it would only move the question a step further back to, "What, then, accounts for the distribution of these advanced cases in the whole ares ?"

The fact is that Professor Delépine has not taken into account, as a possible factor in the problem, a most powerful influence affecting the prevalence of tuberculosis-one to which, during the past ten jears, I have repeatedly called attention-namely, the influence of strong prevalent rain-bearing winds. These winds, I have shown over and over again, have a most remarkable power of increasing the mortality from human taberculosis of the lungs in localities exposed to them, and, as I have more lately indicated, of similarly increasing the mortality from other forms of human tuberculosis. ${ }^{5}$ It is not unreasonable to suppose that they may similarly influence the distribution of bovine taberculosis, though this has not hitherto been suggested. Dr. Delépine's maps afford a unique opportunity of ascertaining whether they do so or not. I propose to show that they do, and that the "cause capable of overpowering the most favourable conditions," which he found to be interfering with his conclusions, was just this influence of wind (possibly together with others which are as yet unknown); also that when steps are taken to prevent the interference of wind exposure with the other investigation, the relation between prevalence of taberculoas mastitis and farm management seems (if I rightly understand and interpret his figures and statements) to become capable of proof.

Before undertaking the detailed examination of the topography of so wide an area it is obviously necessary to inquire into the nature of the available material, in order to ascertain how far satisfactory conclusions may be based upon it; so that it is in no carping spirit that I review the limitations of the very valuable facts which Professor Delépine has presented.

In the first place, the farms indicated are, in many dis. tricts, only a few of the milk.supplying farms in those districts, and it might be alleged that these relatively fow farms cannot be regarded as representative of their districts. But seeing that they are selected simply because they supply Manchester with milk, and for no other reason, I take it that they may reasonably be regarded as repre. sentative of their surroundings, provided a considerable number are grouped together. Dr. Delépine has evidently taken this view.

Again, farms remote from Manchester have apparently 
been less often inspected than farms nearer to it, and so the remoter farms may seem freer from tuberculosis than is really the case. There is no escaping from this possibility, and the only means of avoiding error from it is to constantly bear it in mind. Dr. Delépine draws attention to it, but evidently considers any error produced by it will be inconsiderable.

Farther, in the maps supplied in the Proceedings it has been found impossible, it is stated, to ensure entire accuracy "in square mile areas where farms were numerous." But by tracing out Professor Delépine's mile and four mile squares on Bartholomew's excellent reduced Ordnance Survey Maps (half an inch to the mile, with colours to indicate heights), I believe I have been able to identify the situation of his farms with at least onough certainty to draw the conclusions which follow.

It has also to be remembered that the artificial rednc. tion, so to speak, of the tuberculosis in the farms by removal of infected cattle must tend to reduce the contrasts created by natural predisposing influences. About Manchester itself, especially, this is likely to be the case where the farms are more fully under control, and where so much has evidently been done by the sanitary anthorities to reduce the amount of the disease.

Lastly, when one comes to discuss together the inflaences of wind exposare and of farm manegement, as only a general ides of the positions of the 385 farms used by Professor Delépine is given in the investigation of the effects of the latter, it will be seen to be impossible to come to any positive conclusion, except that his proposition, whilst extremely probable, still remains to be proved.

In short, it seems to me there is, in Professor Delépine's paper and maps, material provided of a very valuable kind for the investigation of the relation between strong, preva. lent rain-bearing winds and the distribution of bovine taberculous mastitis. To that investigation I will first address myself.

Afterwards, should such a relation be clearly shown to exist, it should be possible, when the masking effect of such an influence is aroided, to show that the relation between bovine tuberoulous mastitis and farm management may thereby be made easier to examine.

Incidentally, it will be necessary to consider what poseible influences may be exercised by soil and altitude.

Influman of Prefalent Rain.bearing Winds.

The area discussed in Dr. Delépine's paper is divided by the Pennine Chain into a western region of flat or undulating country reaching from North Lancashire into North Shropshire, and an eastern region of hills and valleys stretching across into Yorkshire, Derbyshire, and Staffordshire.

The western region is swept freely by the prevalent rain-bearing winds of this country-the south-west, west, and north-west-down, at all events, to nearly the latitude of Chester (Zone XxII), where the Welsh mountaing begin to afford some shelter from the west and south west winds, and to give, about the latitade of Ellesmere (Zone XXVIII), some shelter also from the north.west.

The eastern region, on the other hand, is predominantly a region of shelter from all these winds, most of the farms lying in valleys which afford pretty effectual protection. It must not, however, be supposed that all of these farms are thus protected; some stand high in apparently wind. swept situations. The contrast, therefore, between the eastern and the western regions as regards such shelter and exposure is not absolute but relative, yet is evidently so pronounced as to afford a very valuable opportunity for investigating the relation between prevalence of bovine tuberculous mastitis and exposure to these winds.

The comparison between shelter and exposure may be best made by dividing the whole area into districts, which I shall now proceed to describe, indicating in each instance not merely its exposure or shelter in respect of westerly winds, bat also its geological structure and elevation; for both of these latter factors require to be taken into account - the first because it does actually sometimes affect the frequency of tuberculosis, at all events in man; the second becanse it is popularly supposed to do so.

C to G, IX to XIII.-This district contains the few farms which lie out on the flats of Lanceshire in the Zones IX to XIII; they stand on a slightly undulating surface of upper and lower trias (Keuper marl, raised beach and Bunter sandstone) at an elevation of only from about 20 to 100 feet above sea level except a single farm rather higher. There are only 13 of them, and one was tuberculous, giving a percentage of 15.4. Their fewness, their distance from Manchester, and the fact of their slight elevation not exposing them very much to the wind, as well as the comparatively pervious soil, makes these difficult to lay stress on.

I to L, IX to XIII.-The hill farms of Zones IX to XIIr are included in this district. Most of them are in Ribbledale, from which the hills must block ont west and north. west winds considerably, and whose kink near its entrance probably shats out much of the south.west; other farms lie in even more sheltered situations. They stand at heights varying from about 150 to 750 feet, often on steen sloper, on a soil chiefly composed of the Yoredale series of rocks, a few, however, resting on millstone grit or on coalmessures. Most, $T$ imagive, can be classed as sheltered. Out of 66, only 7, or 10.6 per cent., were found to be tuberculous.

Zones XIV to XVII.-Almost all the farms in these zones cluster in and about North Manchester, at eleva. tions of about from 20 to 500 feet-mostly between 200 and 400 feet-in situations exposed for the most part to westerly winds. They nesrly all lie on coal-measures, but there are a few on millstone grit or on trias. Amongst 101 only 15, or 14.8 per cent., were found to be taber. culous. It must, however, be remembered that Dr Delépine points out that the farms in and round Man. chester are exceptional in the control exercised over them and the great improvements effected by the sanitary anthorities. The lowness of these figures may, therefore be reasonably attributed to those improvements. At al events, the suspicion that it may be so attributable cannot be pat aside. To this I shall refer again presently.

$O$ to $M, X V I I I$ and XIX.-The majority of these farms also are grouped in and round Manchester, this time on its southern side. The majority are on trias, at elevations of about from 70 to 300 feet. There are 77 of them, and 15 were found tuberculous - that is, 19.4 per cent. It is possible that these farms also have been improved by the care of the sanitary authorities of Manchester, and, bat for that, might have shown a higher percentage of tuberculous disesse.

Both of these two last districts, being close to the pablic health anthorities, have doubtless been several times inspected, and probably present their true percentage of taberculosis.

$N$ to $P, X V I I I$ and $X I X$.-This distriot contains a small group of sheltered farms (most of them, at all events, are sheltered) lying amongst the hills between Stockport and Glossop on coal-measures, at hejghts varying from about 350 to 800 feet. There are 24 of them, and 3 were tuber. culous, or 12.5 per cent. Not being far from Manchester, this low figure is probably not due to infrequent inspection.

$C$ to $H, X X I I$ to $X X I V$.-The slopes of Delamere Forest afford an interesting comparison. The forest forms a ridge with a general elevation of about $400 \mathrm{ft}$. running from NNW. to SSE., and at least 18 miles away from the northern commencement of the Welsh mountsins, which there rise to about 1,200 to 1,300 feet. The forest affords protection from west and south-west winds to farms on its eastern side, but practically none from north. west winds.

On its westerly slope (G, XXII to XXIV, except one farm in G, XxII, which is clearly on the esstern side) there are 50 farms, of which 20 , or 40 per cent., were found taberculous; and west again of these, in perhaps a rather less exposed situation (E and F, XXII and XXII), 20 farms had 7 tuberculous, or 35 per cent., 4 of these 7 being on a mound rather higher than the majority of the rest.

On the easterly side of the forest, on the other hand (H, XXIr to XXIv, with the single farm taken, as above, from G, xxIr), out of 19 farms only 3 , or 15.8 per cent., were tuberculous.

The heights of these farms in this area vary from about 30 to 400 feet. Those on the west of Delamere Forest are mostly on lower trias, those on the east of it on upper trias. Those on the east are certainly more elevated than those on the west, and it is possible that the very high percentages to the west of the forest were partly due to dampness of subsoil close to the river Gowy, but this will not entirely explain the facte, since many of the tabercu. lous farms were well above the river, 
I to $M, X X$ to $X X I V$.- This is a 20 mile square lying south of Manchester, consisting of undulating country, low round river beds on the west, but esstwards rising to a height of about 500 feet towards Macclesfield and Congleton. It is generally very exposed, except in its westerly lower lands and in its south-eastern corner; the subsoil is practically all of upper trias; 520 farms bere showed 144 tuberculous, or 27.6 per cent.

It is also instructive to compare the five constituent north to south divisions of this area, I, J, K, L, M. In the most westerly, I, the least exposed, the percentage was 15.7 ; in the next two, $J$ and $K$, well exposed to west, south-west, and north-west, 31.1 per cent. and 30.6 per cent. respectively, but in the two most easterly, $L$ and $M$, the percentage fell to 27.1 and 27.6 ; in $\mathrm{M}$, at all events, a good many of the farms were in shelter at its southern extremity. Being close to Manchester, it is possible that this area has been unusually often inspected, which may have somewhat raised the figures.

In striking contrast to this specially exposed area are the much more sheltered areas across the hills eastwards.

$N$ to $P, X X$ to $X X I I$.-Behind Macclesfield and about Chapel en-le.Frith, mostly well sheltered in high hills at elevations varying apparently from about 500 to 1,000 feet, lie 169 farms, on soil chiefly composed of Yoredale rocks, but also a good deal on coal-mersures and millstone grit. Of these 169 only 24, or 14.2 per cent., were tuberculous. These are no further from Manchester than the last, and there is therefore no resson to suspect the figures of being unduly low from want of inspection. The following, however, are further off, and hence may have been less often inspected, and thus present unduly low percentages.

$N$ to $P, X X I I I$ to $X X V I$.-Round Leek in Staffordshire, elso mostly in shelter, at heights apparently varying about from 400 to 1,000 feet, on soil chiefly and about equally composed of cosl-measures and Yoredale rocks, but also partly of millstone grit and lower trias, there are 144 farms, with only 21 , or 14.5 per cent., taberculous.

$Q$ to $S, X X$ to $X X I I$.- Even more remarkable is a group of 43 farms near Bakewell, which at elevations apparently of about 400 to 1,000 feet, almost wholly on Yoredale rocks and in marked shelter, only showed 5 tuberculous, or 11.6 per cent.

$Q$ to $\mathcal{B}, X X I I I$ to $X X V I$.-South of Bakewell, at heights probably varying from 300 to 1,000 feet, and also practically wholly on Yoredale rocks, 172 farms gave 29 infected farms, or 16.8 per cent. Most of these farms are in shelter, but some are evidently in very wind-swept places.

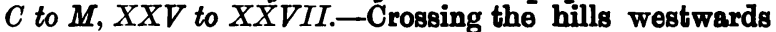
again, an area open mostly to the north-west, but less exposed than the areas directly north of it to the west and south-west winds (since it is more under the lee of the Welsh mountains), has 97 farms, with 21 , or 21.6 per cent. tuberculous. These farms lie almost all on upper or lower trias, at elevations of about 150 to 300 feet.

$C$ to $M, X X V I I I$ to $X X X I$. - Still further south and still more under the shelter of Wales lies a district which, being more undulating, is also more self-sheltering. Here, of 40 farms standing at elevations of about 200 to 300 feet, almost all on upper and lower trias, 6 were found tuberculous, or 15 per cent.

$N$ to $O, X X V I I$ to $X X X$.-Lastly, once more passing eastwards over the hills, a small, well-sheltered group of 19 farms, south of Cheadle, at elevations of about 300 to 500 feet, and practically all placed on upper trias, showed only a single farm, or 5.2 per cent., infected.

It is well to observe that a few farms round Uttoxeter, at lower levels on upper trias, just east of this last group, were very taberculous, but they are in most cases clearly placed in less sheltered situations. Their presence, how. ever, serves to indicate that the more remoteness of thi district need not be held to account-wholly, at all events -for its low percentage.

To make clearer the very remarkable contrast presented by the more exposed and more sheltered districts just described, I have constructed first Table I, which, without taking into consideration any modifying circumstances, compares all the districts on the west of the Pennine Chain with all those in its sheltering valleys. The percentages of the farms found taberculous in the western region are generally considerably greater than in the eastern, and the aggregate figures present a striking contrast.

Table II strengthens this contrast by comparing the
TABle I.-Gene Ral Comparison of the Western Region WITH THE EASTERN. Western.

\begin{tabular}{|c|c|c|c|c|c|c|}
\hline District. & & Soil. & 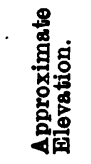 & 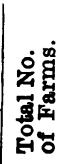 & 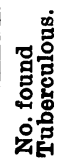 & 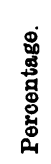 \\
\hline C to $\mathrm{G}, \mathrm{IX}$ to $\mathrm{XIII}$ & ... & Trias & Feet. & 13 & 1 & 15.4 \\
\hline xIV to XVII ... & $\cdots$ & $\begin{array}{l}\text { Cosl- } \\
\text { messures }\end{array}$ & $20-500$ & 101 & 15 & 14.8 \\
\hline $\mathbf{C}$ to $\mathbf{M}, \mathbf{x}$ IIII to $\mathrm{xIx}$ & ... & Trias & $70-300$ & 77 & 15 & 19.4 \\
\hline C to F, XXIr and XxrII & $\cdots$ & Trias & $30-100$ & 20 & 7 & 35.0 \\
\hline$G, \times x I I$ to $X X I V$ & ... & Trias & $78-450$ & 50 & 20 & 40.0 \\
\hline H, $\operatorname{xxII}$ to $\operatorname{xxIV} \quad \ldots$ & ... & Trias & $70-400$ & 19 & 3 & 15.8 \\
\hline I to $\mathbf{M}, \mathrm{xx}$ to $\mathrm{xxIV} \ldots$ & $\cdots$ & Trias & $66-550$ & 520 & 144 & 27.6 \\
\hline $\mathbf{C}$ to $\mathbf{M}, \operatorname{xx\nabla }$ to $\operatorname{xxvII}$ & $\cdots$ & Trias & $150-400$ & 97 & 21 & 21.6 \\
\hline $\mathbf{C}$ to $\mathbf{M}, \mathrm{XXVIII}$ to $\mathrm{XXXI}$ & $\cdots$ & Trias & $200-300$ & 40 & 6 & 15.0 \\
\hline Totals ... & $\cdots$ & 一 & - & 937 & 232 & - \\
\hline Average & $\ldots$ & - & 一 & - & - & 24.7 \\
\hline
\end{tabular}

Eastern.

\begin{tabular}{|c|c|c|c|c|c|c|}
\hline I to $\bar{E}, \mathrm{IX}$ to $\mathrm{XIII} \quad \ldots$ & ... & Yoredale & $150-750$ & 66 & 7 & 10.6 \\
\hline$N$ to $P, x V I I I$ and $x I x$ & ... & $\begin{array}{l}\text { Cosl- } \\
\text { measures }\end{array}$ & $350-800$ & 24 & 3 & 12.5 \\
\hline N.to $P, \mathrm{xx}$ to $\mathrm{xxII}$ & ... & $\begin{array}{l}\text { Yoredale, } \\
\text { Cosl- } \\
\text { messures, } \\
\text { Millstone grit }\end{array}$ & $500-1,000$ & 169 & 24 & 14.2 \\
\hline$N$ to $P, x x I I I$ to $x \times \nabla I$ & $\cdots$ & $\begin{array}{l}\text { Yoredale, } \\
\text { Cosl- } \\
\text { measures, } \\
\text { Some trias, } \\
\text { and mill- } \\
\text { stone grit }\end{array}$ & $400-1,000$ & 144 & 21 & 14.3 \\
\hline N O, $\operatorname{xxVII}$ to $\mathrm{xxxI} \ldots$ & $\cdots$ & Trias & $300-500$ & 19 & 1 & 5.2 \\
\hline $\mathrm{Q}$ to $\mathrm{S}, \mathrm{xx}$ to $\mathrm{xxII} \ldots$ & $\cdots$ & Yoredale & $400-1,000$ & 43 & 5 & 11.6 \\
\hline $\mathrm{Q}$ to $\mathbf{8}, \mathbf{X X I I}$ to $\mathrm{XXVI}$ & ... & Foredale & $300-1,000$ & 172 & 29 & 16.8 \\
\hline Totals ... & $\cdots$ & - & - & 637 & 90 & - \\
\hline Average & $\ldots$ & - & - & - & - & 14.1 \\
\hline
\end{tabular}

western and eastern figures at corresponding latitudes. Here Zone xIv to xvII is only omitted because it con. tains no sheltered district to compare with the exposed.

Amongst the districts in Table I are, however, incladed two districts which I have referred to as doubtful, namely, those including Manchester and its immediate neighbourhood where special measures have been taken to reduce the frequency of tuberculosis, namely, XIV to XVII and $\mathbf{C}$ to $\mathbf{M}$, Xvirr and xrx.

Another district, $\mathbf{C}$ to $\mathbf{M}$, xxvIII to XxxI, which is probably considerably sheltered, as I have indicated, not only by the mountains of Wales, but by its own undulations, is also

Table II.-Comparing Percentages of Western and Eastern Regions at Corresponding Latitudes.

\begin{tabular}{|c|c|c|c|c|}
\hline \multicolumn{3}{|c|}{ Western. } & \multicolumn{2}{|l|}{ Eastern. } \\
\hline Dist & rict. & Percentage. & District. & Percentage. \\
\hline IX to $\mathrm{XrII}$, & to $\mathbf{G} \quad \ldots$ & 15.4 & IX to XIII, I to $L \quad \ldots$ & 10.6 \\
\hline$x \nabla I I$ and $x$ & $\mathrm{Ix}, \mathrm{C}$ to $\mathbf{M}$ & 29.4 & $x \nabla m$ and $x I x, N$ to $P$ & 12.5 \\
\hline \multirow{4}{*}{$x x$ to $x \times r v$} & (C to F ... & 35.0 & ( N to $P . .$. & 14.2 \\
\hline & G $\quad \ldots$ & 40.0 & $x x$ to $x x I I\left\{\begin{array}{l}Q \text { to } 8 . . .\end{array}\right.$ & 11.6 \\
\hline & H $\quad \ldots$ & 15.8 & & \\
\hline & I to $\mathbf{M} . .$. & 27.6 & $x \times I I I$ to $x \times v I\{N$ to $P$ & 14.3 \\
\hline $\mathbf{x x v}$ to $\mathrm{XxV}$ & II, $\mathrm{C}$ to $\mathrm{M}$ & 21.6 & & 16.8 \\
\hline$x x v i n$ to $x$ & $\mathbf{x I}, \mathbf{C}$ to $\mathbf{M}$ & 15,0 & XXVII to $x \times x I, N, O$ & 5.2 \\
\hline
\end{tabular}


included amongst those which are exposed; and so is district $\mathrm{H}$ XXII to XXîn, which, as has been seen, is only exposed to the north-west. Omitting these four districts one obtains Table III, where the more exposed districts

Table III.-Table I with Doubtful Districts Omitted. Western.

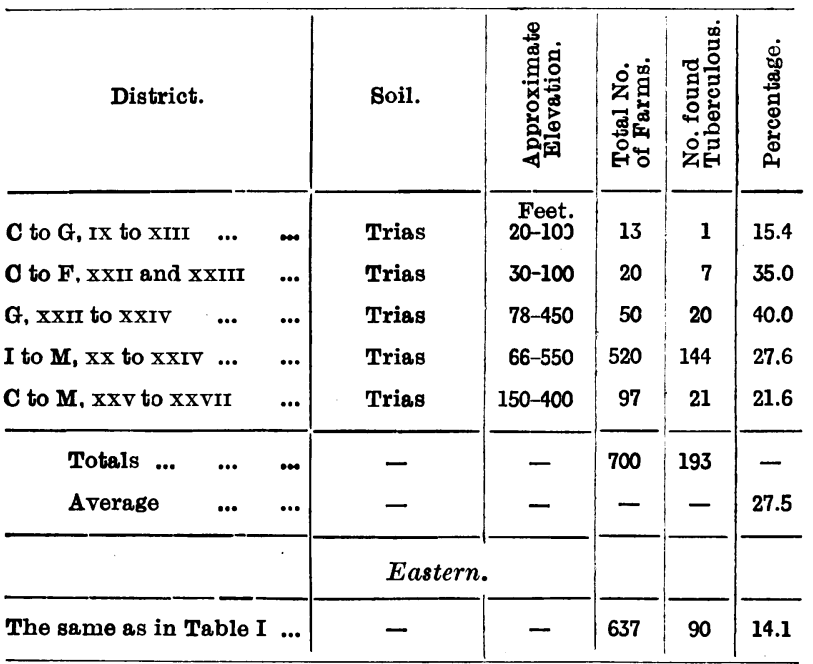

are seen to have nearly twice the percentage of taberculous farms that the more sheltered districts have.

But even this striking contrast does not show the full measure of the difference between exposure and shelter. Table IV gives the comparison between 52 fully exposed

TABLE IV.二COMPARISON OF EVIDENTLY WELL-EXPOSED WITH EVIDENTLY WELL-SHELTERED FARMS OVER 300 FEET HIGH.

\begin{tabular}{|c|c|c|c|c|c|c|}
\hline District. & & Soil. & 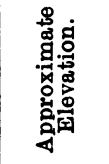 & 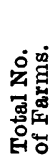 & 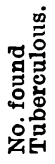 & 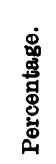 \\
\hline $\begin{array}{c}\text { Exposed. } \\
\text { In } \mathbf{M}, \mathrm{xx} \text { to } \mathrm{xxIV}\end{array}$ & $\cdots$ & Trias & $\begin{array}{r}\text { Feet. } \\
400-550\end{array}$ & 52 & 20 & 38.4 \\
\hline $\begin{array}{l}\text { Sheltered. } \\
\text { In } \mathbf{Q} \text { to } \mathbf{S}, \mathbf{x x} \text { to } \times \mathbf{x} \mathbf{I}\end{array}$ & $\cdots$ & Yoredale & $300-1,000$ & 82 & $7^{*}$ & 8.5 \\
\hline In $N, O, x x v I I$ to $x x x t$ & $\ldots$ & Trias & $300-500$ & 19 & 1 & 5.2 \\
\hline
\end{tabular}

* Of the 7 tuberculous 5 were over 600 feet high.

t The farms in this district, though few, are more comparable in soil and elevation.

farms just west of Macclesfield on high ground fronting the west, and 82 farms evidently very well protected in the valleys between Buxton and Warksworth. Here the exposed district shows a percentage of tuberculous farms more than four times as great as does the sheltered!

Bat, it will be asked, have soil and altitude nothing to do with the origin of these differences ?

The Infudence of SoIr.

I have elsewhere shown that the influence of soil on the prevalence of human phthisis is decidedly less powerfal than the influence of prevalent rainy winds. For the present inquiry there is not sufficient material to enable one to decide on the part it plays in determining the incidence of bovine tuberculous mastitis. For that purpose soils must be compared in shelter, and, as the great majority of the sheltered farms in this area are on Yoredale rocks only, it seems undesirable to found conclusions on the comparatively few placed on other formations. Yet it is worth noticing that $\mathrm{N}, \mathbf{0}$, XXvII to XXXI, is the only sheltered district standing on trias, and that it has the lowest percentage of taberculous farms.

On the other hand, it may be confidently stated that soil has nothing to do with creating the marked differences between the more exposed and the more sheltered districts, for almost all the exposed districts are on trias, which I find is often associated in England with relatively low human phthisis mortality, whereas most of the shel. tered districts are on Yoredale rocks, which seem often associated with relatively high human phthisis death-rates in this country. In fact, it is not impossible that soil here tends to lessen the contrast created by rain-bearing wind.

The Infloence of Altitude.

I have shown elsewhere that there is no valid evidence in favour of any influence of altitude per se on the pre. valence of human phthisis, and the only effect I can trace from it in this country is an apparent increase of the effects of wind exposure in elevated situations.

Table V will, I imagine, deter those who are not acquainted with my work from assigning to altitude here any very important rôle.

Table V.-Comparison of Altitudes, Western and Eastern SEPARATELY, OMITTING THE DOUBTFUL DISTRICTS.

\begin{tabular}{|c|c|c|c|c|c|c|c|}
\hline \multicolumn{4}{|c|}{ Western. } & \multicolumn{4}{|c|}{ Eastern. } \\
\hline Altitude in & \multicolumn{2}{|c|}{ Feet. } & \multirow{2}{*}{$\begin{array}{c}\begin{array}{c}\text { Percentage } \\
\text { as above. }\end{array} \\
15.4\end{array}$} & \multicolumn{3}{|c|}{ Altitude in Feet. } & \multirow{2}{*}{$\begin{array}{c}\begin{array}{c}\text { Percentage } \\
\text { as above. }\end{array} \\
5.2\end{array}$} \\
\hline $20-100 \ldots$ & $\ldots$ & ... & & $300-500$ & ... & $\ldots$ & \\
\hline $30-100 \ldots$ & $\ldots$ & $\ldots$ & 35.0 & $150-750$ & $\ldots$ & ... & 10.6 \\
\hline $78-450 \ldots$ & $\ldots$ & $\ldots 1$ & 40.0 & $350-800$ & $\ldots$ & $\ldots$ & 12.5 \\
\hline $150-400 \ldots$ & $\ldots$ & $\ldots$ & 21.6 & $300-1,000$ & $\ldots$ & $\ldots$ & 16.8 \\
\hline \multirow{2}{*}{$66-550 \ldots$} & $\ldots$ & ... & 27,6 & $400-1,000$ & $\ldots$ & $\ldots$ & 14.3 and 11.6 \\
\hline & & & & $500-1,000$ & $\ldots$ & $\ldots$ & 14.2 \\
\hline
\end{tabular}

There can, in fine, I submit, be no reasonable doubtassuming, as we must, that Dr. Delépine's published maps are not wholly devoid of value - that amongst the farms here indicated during the years 1896 to 1909 , exposure to the prevalent rain-bearing winds tended powerfully to increase the prevalence of bovine tuberculous mastitis.

The Influence of Farm Management.

This brings me to the consideration of the difficulties which have unfortunately hampered Professor Delépine in his research.

In view of the powerfal influence of wind exposure which I have just shown to exist, it is obviously no longer admissible to compare together districts of quite different conditions as regards wind exposure in order to trace a connexion between farm management and bovine tuberculosis. Dr. Delépine, in the paragraph I quoted and marked $B$ at the beginning of this paper, has, as I have already pointed out, satisfactorily explained one apparent contradiction. But, in the paragraph which I marked $A$, his real difficulty has arisen from comparing together zones of quite different exposure conditions. Difficulties so created are of no final impor. tance; and, were one aware of the exact location of the 385 farms he used for his investigation, it is possible one could at once establish the fact of the influence of farm management by the comparison of farms in shelter; or, failing this comparison which is the safest method to pursue, by comparison of farms in comparable situations as regards wind exposure and shelter. I say "possible" because, as I have already pointed out, without knowing the precise position of these farms one can draw no certain conclusions.

It is worth noticing that the farms in and about Man. chester afford a marked contrast between the sanitary conditions presented by the tuberculous and the non. taberculous; also that south of Zone XXII-that is, where a large proportion of the farms begin to be in shelterthe relation between farm management and tuberculosis is stated to come out distinctly.

In view of the great probability that the relation between bovine tuberculosis and farm management is a real and intimate one and of the great importance of actually showing it to be so, it would seem worth while to reconsider the subject on the lines which I have just ventured to suggest. It only remains to thank Prolessor Delépine for having afforded me, by his valuable paper, a unique opportunity of examining the effect of these winds on a form of bovine taberculosis, and to congratulate Manchester on its public health administration.

1 Proc. Roy. Soc. Med., vol. iii, No. 7, May, 1910, Epidemiological Section. pv. 224 and 227. 2 Pages 238 and 239. 3 Page 219. Page 253 SThe Influence of Strong. Prevalent, Rain-bearing Winds on the Prevalence of Phthisis, 1910 . 